\title{
Phytochemical, Proximate and Antifungal Studies on Phoenix dactylifera $\mathbf{L}$.
}

\author{
Onuminya, Temitope Olabisi ${ }^{1}$ and Opaluwa, Ojotule ${ }^{2}$ \\ ${ }_{1,2}$ (Department, of Botany, University of Lagos, Akoka, Lagos, Nigeria)
}

\begin{abstract}
Date fruits are one of the very common fruits known to man having a lot of vitamins and minerals necessary for the wellbeing of an individual. In this study, the aqueous, ethanolic, n-hexane and diethylether extracts of date fruits (Phoenix dactylifera L.) obtained from a local market were analyzed for their phytochemical and proximate composition as well as antifungal properties on two different fungi species (Loramyces macrosporus and Aphanomyces laevis). Phytochemical screening showed that there was the presence of alkaloids, flavonoids, tannin, saponin, teterpenoid, steroids and phenols while the proximate analysis showed the abundance of carbohydrate as well as low concentrations of protein, crude fat and moisture. The aqueous extract of the fruit had a higher phytochemical profile than the other extracts hence was used in the antimicrobial studies. Antifungal studies using varying concentrations $(200 \mathrm{mg} / \mathrm{ml}, 400 \mathrm{mg} / \mathrm{ml}, 1000$ $\mathrm{mg} / \mathrm{ml}$ ) of the aqueous extract of the fruit showed that increase in the concentration of the extract, was directly proportional to the increase in zones of inhibition observed in the fungi tested. The extracts of the date fruits showed a correlation between their phytochemical composition and the fungal resistivity. These findings can be seen as additional knowledge on the importance of having dates in our diet and also as a natural antifungal agent for daily use.
\end{abstract}

Keywords: Date fruit, Fungistatic, Medicinal plant, Phytochemistry

\section{Introduction}

A wide array of natural foods has been known to exhibit many antimicrobial properties and have been screened and discovered to have many antimicrobial compounds. As industrialisation and technology continues to grow, there is a need to pay a close attention to human health and human how nature's gifts can be used to combat microbes that cause increasing health issues. For centuries, Phoenix dactylifera L., commonly known as the date palm, has been cultivated for its fruit by the Arabs although the exact origin has not been verified (Manickavasagan et al, 2012). In Nigeria, it is commonly found in the Northern region and sparsely found in the Southern and Western states. Date palm leaves are often used to make mats, baskets, crates and fans for religious purposes. The petiole of the plant is used as a source of cellulose pulp. Mature leaves are used as insulating boards, saddles, ropes, coarse clothes and hats due to their richness in fibre. They also represent a source of fuel and raw material for making fishing implements and objects such as walking sticks and brooms. The fruits are berries with varying shape, size, colour and chemical composition (Zaid and de Wet 2002; AlYahyai and Kharusi 2011). They are very sweet, rich in carbohydrates, dietary fibres and certain essential amino acids, vitamins and minerals. Previous studies have shown that the date fruit contains anthocyanins, phenolics, sterols, carotenoids, procyanidins and flavonoids and it is known to show free radical scavenging, antioxidant, antimutagenic, antimicrobial, antidiarrheal, anti-inflammatory, gastroprotective, hepatoprotective, nephroprotective, anticancer, laxative, and immunostimulant activities (Block et al, 1992; Tapiero et al, 2002; Al-Qarawi et al., 2003; El Hadrami et al, 2005; Foroogh et al, 2008; Manjeshwar et al, 2011). The date fruit has found a niche in science and its experimentation; it is one of the most researched fruits as it has so many properties that make it suitable as not only a delicacy but as a medicine too. In this study, we report the phytochemical and nutritional composition as well as antifungal activity of extracts of date fruit as part of our exploration for new bioactive compounds.

\subsection{Collection of Samples}

\section{Materials And Methods}

The Date fruits were bought from one of the local markets in Lagos popularly known as Idi-Araba Market (Latitude $6^{\circ} 31.152^{\prime} \mathrm{N}$ and Longitude $\left.3^{\circ} 20.932^{\prime} \mathrm{E}\right)$. Qualitative characters of the fruit (type, shape and colour) were assessed and described following Radford et al (1974).

\subsection{Preparation of plant extracts with Distilled Water}

Fruits of Phoenix dactylifera $\mathrm{L}$. were shade dried for $14 \mathrm{dys}$ and then oven dried at $60^{\circ} \mathrm{C}$ to a constant weight. The dried samples were ground to powder using, weighed and divided into four parts of $150 \mathrm{~g}$ each. Each part 
was soaked in water, ethanol, $\mathrm{n}$-hexane and diethylether for a period of $72 \mathrm{~h}$ respectively. The extracts were then filtered with What-man's filter paper and the filtrates concentrated at $40^{\circ} \mathrm{C}$ using a rotary evaporator.

\subsection{Phytochemical Analysis of the Plant Extract}

The quantitative and qualitative phytochemical analysis of the plant sample was carried out for the presence of anthraquinones, tannins, saponnins, steroids, cardiac glycosides, flavonoids, terpenoids, phenols and alkaloids following Sofowora (1993).

\subsubsection{Qualitative Analysis}

Test for Tannins: $1 \mathrm{ml}$ of extract added to $1 \mathrm{ml}$ of $3 \% \mathrm{FeCl}_{3}$. Greenish-black coloration shows presence of Tannin.

Test for Saponins: $2 \mathrm{~g}$ of powdered sample boiled with $20 \mathrm{ml}$ of water for $5 \mathrm{mins}$ at $100^{\circ} \mathrm{C}$, filtered. $10 \mathrm{ml}$ of the filtrate was added to $5 \mathrm{ml}$ of water and shaken to observe for stable froth, add 3 drops of olive oil and shake vigorously for formation of emulsion.

Test for Terpenoids: $1 \mathrm{ml}$ of extract added to $1 \mathrm{ml}$ of chloroform and few drops of concentrated hydrochloric acid underplayed to form a layer and observed. Brownish coloration indicated presence of Terpenoid.

Test for Steroids: $1 \mathrm{ml}$ of extract added to $1 \mathrm{ml}$ acetic anhydride was added to few drops of sodium hydroxide. Colour change from violet to blue green indicates presence of steroid.

Test for Flavonoids: $1 \mathrm{ml}$ of extract was added to $1 \mathrm{ml}$ of dilute $\mathrm{NaOH}$. Presence of cloudy precipitate shows the presence of flavonoid.

Test for Alkaloids: The powdered sample of the date fruit, $0.2 \mathrm{~g}$ was boiled with $2 \mathrm{ml}$ of $2 \%$ hydrochloric acid, filter and add 2 drops of Dragendorff. Orange-red precipitate showed the presence of Alkaloid.

Test for Anthraquinones: One $\mathrm{ml}$ of extract was added to few drops of $1 \mathrm{M}$ sodium hydroxide, observed. Red coloration shows presence of combined anthraquinone.

Test for Cardiac glycosides: Extract measured at $0.1 \mathrm{ml}$ was added to $1 \mathrm{ml}$ of glacial acetic acid and 1 drop of $3 \% \mathrm{FeCl}_{3}$ underlayed with $1 \mathrm{ml}$ of concentrated hydrochloric acid was observed. Brown ring at the interphase showed presence of cardiac glycoside.

Test for Phenols: $2 \mathrm{ml}$ of extracts was added to $5 \mathrm{ml}$ of water and warmed between $45-50^{\circ} \mathrm{C}, 2 \mathrm{ml}$ of $3 \% \mathrm{FeCl}_{3}$ was added to it and observed. Formation of green or blue colour shows presence of phenol.

\subsubsection{Quantitative Analysis}

Flavonoids: To $1 \mathrm{ml}$ of the extract, $4 \mathrm{ml}$ of water was added and incubated for $5 \mathrm{mins} .0 .3 \mathrm{ml}$ of $5 \%$ sodium nitrate and $0.3 \mathrm{ml}$ of $10 \%$ aluminum chloride was added to the solution and incubated again for $6 \mathrm{mins} .2 \mathrm{ml}$ of $1 \mathrm{M}$ sodium hydroxide and $2.4 \mathrm{ml}$ of $\mathrm{dH}_{2} \mathrm{O}$ was added to the solution and absorbance at 510 against blank Quercetin as standard.

Alkaloids: $20 \mathrm{ml}$ of $10 \%$ acetic acid in ethanol was added to $0.5 \mathrm{~g}$ of powdered sample and incubated for $4 \mathrm{~h}$. The solution was filtered and filtrate concentrated to reduce to $1 / 4 \mathrm{in}$ a water bath. Concentrated ammonium hydroxide was added, filtered with an already weighed filter paper and rinsed with $1 \%$ ammonium hydroxide and dried in an oven. The weight of the filter paper is retaken and recorded.

Tannin: $1 \mathrm{ml}$ of extract, $5 \mathrm{ml}$ of water and 4 drops of tannin reagent were mixed in a cuvette and the absorbance was read at $720 \mathrm{~nm}$.

Saponin: To $1 \mathrm{~g}$ of sample, $25 \mathrm{ml}$ of isobutyl alcohol was added, shaken and filtered with filter paper. After 5 mins $10 \mathrm{ml}$ of $40 \%$ magnesium carbonate was filtered against $1 \mathrm{ml}$ of the filtrate and $2 \mathrm{ml}$ of $5 \% \mathrm{FeCl}_{3}$. The volume was made up to $50 \mathrm{ml}$ with distilled water and incubated for 30 mins. Absorbance was read at $380 \mathrm{~nm}$. Terpenoids: $20 \mathrm{ml}$ of chloroform methanol was added to $0.5 \mathrm{~g}$ of powdered sample, shaken, incubated for 15 mins and centrifuged for 15 mins. The supernatant was decanted and rewashed with $20 \mathrm{ml}$ of chloroform methanol and re-centrifuged. The precipitate was dissolved in $40 \mathrm{ml}$ of $10 \%$ sodiumdodecyl sulphate solution and $1 \mathrm{ml}$ of $0.01 \mathrm{M}$ iron iii chloride, incubated for 30 mins and absorbance at $510 \mathrm{~nm}$ was taken.

Steroids: $3 \mathrm{ml}$ of $0.1 \mathrm{M}$ sodium hydroxide, $2 \mathrm{ml}$ of chloroform, $3 \mathrm{ml}$ of ice cold acetic anhydride and 2 drops of concentrated sulphuric acid was added to $2 \mathrm{ml}$ of extract. Absorbance at $420 \mathrm{~nm}$ was taken.

Combined Anthraquinone: $5 \mathrm{ml}$ of aqueous methanol was added to $1 \mathrm{~g}$ of sample, incubated for 10 mins and filtered. $1 \mathrm{ml}$ of the extract, $1 \mathrm{ml}$ of 2\% 3-5 DNS (Dinitrosalicyclic acid) and $1 \mathrm{ml}$ of 5\% sodium hydroxide as boiled for 2 mins at $95^{\circ} \mathrm{C}$ until brick red precipitate observed (N.B: a change in color from yellow to brick red shows positive presence of combined anthraquinone)

A filter paper was weighed and used to filter the boiled sample then oven dried at $50^{\circ} \mathrm{C}$ and reweighed.

$\%$ combined anthraquinone $=$ Final weight - Initial weight $\times 100$

$$
\text { Weight of sample }
$$


Cardiac Glycosides: $10 \mathrm{ml}$ of $70 \%$ alcohol was added to $1 \mathrm{~g}$ of sample, left to sit for $2 \mathrm{~h}$ and filtered. $4 \mathrm{ml}$ of $12.5 \%$ lead acetate and $8 \mathrm{ml}$ of $4.77 \%$ disodium hydrogen phosphate was added to the filtrate and made up to 32 $\mathrm{ml}$ with distilled water. $5 \mathrm{ml}$ of Buljets reagent was then added and the absorbance at $495 \mathrm{~nm}$ read.

Phenol: One $\mathrm{ml}$ of extract had $0.4 \mathrm{ml}$ proline added and left to sit for 5 mins. $4 \mathrm{ml}$ of $75 \% \mathrm{Na} 2 \mathrm{Co} 3,4.6 \mathrm{ml}$ of $\mathrm{dH}_{2} \mathrm{O}$ was added and incubated for $1 \mathrm{~h} 30$ mins and the absorbance of $565 \mathrm{~nm}$ was taken against the standard prepared at ranges of $0,50,100,150,200,250 \mathrm{mg} / \mathrm{L}$.

2.4. Determination of Antimicrobial Activity

2.4.1. Organisms

The microorganisms used in this study consist of two test fungi Loramyces macrospores and Achyla racemosa. 2.4.2. Media

Sabouraud dextrose agar (SDA) was used in the culturing and antifungal screening of the date fruit extracts. This was prepared according to the manufacturer's instructions and Ampicillin was used as a standard antibacterial agent to avoid the growth of bacteria in the medium.

2.4.3 Antimicrobial Agents

The chemotherapeutic agent used in the test as positive control was Fulcin $10 \mu \mathrm{g} / \mathrm{ml}$.

2.4.4 Antimicrobial Screening of Plant Extracts

This was carried out using the agar diffusion well antifungal assay method. The pure fungi inoculum was uniformly cut out and dissolved in $5 \mathrm{ml}$ of saline solution to release the spores from the fungi culture into the solution. Sterile Petridishes each $90 \mathrm{~mm}$ containing SDA were used. The SDA plates had $0.5 \mathrm{ml}$ of the saline solution containing the fungal spores placed in them and spread with a glass spreader for even distribution around the medium. The medium was then bored with a cork borer to make holes of $6 \mathrm{~mm}$ in diameter. The experiment had aqueous date fruit extracts of varying concentrations $(200 \mathrm{mg} / \mathrm{ml}, 400 \mathrm{mg} / \mathrm{ml}$ and $1000 \mathrm{mg} / \mathrm{ml})$ as the test experiment, the control was divided into Positive control, using $500 \mathrm{~g}$ of a known antifungal drug, Fulcin with trade name REFUCIL and negative control using distilled water. The different concentration of extracts, $200 \mathrm{mg} / \mathrm{ml}, 400 \mathrm{mg} / \mathrm{ml}$ and $1000 \mathrm{mg} / \mathrm{ml}$, were taken in $0.5 \mathrm{ml}$ by a plastic dropper and placed in the 6 $\mathrm{mm}$ diameter holes. The petridishes were then labeled, sealed and incubated for $72 \mathrm{~h}$ at $28^{\circ} \mathrm{C}$ under aerobic conditions (All manipulations were done in sterile conditions). After $72 \mathrm{~h}$ of incubation, inhibition of the fungi zones was obtained by a meter rule as inhibition zone diameter $(\mathrm{mm})$.

\subsection{Proximate Analysis}

2.5.1. Ash (Blight and Dye Method): $1 \mathrm{~g}$ of sample was weighed into a clean oven dried crucible and placed in a blast furnace of $400-600^{\circ} \mathrm{C}$ for $4 \mathrm{~h}$ until whitish grey ash was obtained from the crucible. The crucible was then reweighed.

$\%$ ash $=$ Final weight - Initial weight $\times 100$

Weight of sample

2.5.2. Moisture (Blight and Dye Method): $1 \mathrm{~g}$ of sample was placed in a clean oven dried petridish and kept in an oven for $65^{\circ} \mathrm{C}$ for $6 \mathrm{~h}$ to dry and kept in a desiccator afterwards. The sample was weighed after drying to get the final weight.

$\%$ moisture $=100-\underline{\text { (Final weight }- \text { Initial weight })} \times 100$

Weight of sample

2.5.3. Carbohydrate Determination: $1 \mathrm{~g}$ of sample homogenized in a mortar with $20 \mathrm{ml}$ of $2.5 \%$ of sulphuric acid was poured in a boiling tube and boiled for 10 mins. The solution was filtered and filtrate was made up to $250 \mathrm{ml}$ with distilled water. I ml was taken out of the $250 \mathrm{ml}$ of filtrate and added to $9 \mathrm{ml}$ of water to make 10 $\mathrm{ml}$ of solution. $1 \mathrm{ml}$ was taken to a clean boiling tube and added $4 \mathrm{ml}$ of $0.1 \%$ anthrone reagent and boiled for 10 mins. It was allowed to cool and the absorbance was read at $620 \mathrm{~nm}$.

i.e. Absorbance of sample $\mathrm{x}$ concentration of standard

Absorbance of standard

2.5.4. Lipid Determination (Blight and Dye Method)

$1 \mathrm{~g}$ of sample was weighed and homogenized with chloroform methanol then centrifuged for 10 mins. The beaker was dried in an oven and weighed. The filtrate was decanted and collected and poured into a separating funnel and $10 \mathrm{ml}$ of normal saline was added to it. The lower layer of the solution was collected in a beaker and dried in an oven before being weighed.

$\%$ lipid $=$ Final weight - weight of beaker $\times 100$

Weight of beaker

2.5.5. Protein Determination

Digestion: $1 \mathrm{~g}$ of sample was added to $1 \mathrm{~g}$ of sodium sulphate, $0.1 \mathrm{~g}$ of copper sulphate as well as $20 \mathrm{ml}$ of concentrated sulphuric acid and digested in a fume cupboard, slowly heating until digestion becomes clear pale green. This was allowed to cool and the volume of digested solution was adjusted to $250 \mathrm{ml}$ with distilled water. The solution was poured in a bottle and covered. 
Distillation: The distillation apparatus was steamed and $10 \mathrm{ml}$ of the digest was added into the apparatus. It was allowed to boil and sodium hydrochloride added so that the ammonia is not lost. $50 \mathrm{ml}$ of $20 \%$ Boric acid was added to the distillate containing mixed indicator (methyl red and blue) changes to green.

Titration: The alkaline ammonium was titrated directly with $0.1 \mathrm{M}$ hydrochloric acid. The value, which is the volume of acid used, was recorded.

Protein content $=\underline{(t 5-t 6)} \times 0.1 \times 14 \times \underline{200} \times \underline{100 \times 6.25}$

$$
1000 \quad 30 \quad \text { weight of sample }
$$

Where:

t5 = titre of sample

t6 = titre of blank

\subsection{Morphology}

\section{Results And Discussion}

Interactions with the sellers of the date fruit showed that the fruits were bought from Saudi Arabia due to the fact that the date palm plantations in the north are not enough to cater for the needs of the northerners who relish this fruit talk more of transporting it to other parts of the country. The date fruits bought from the Idiaraba local market is a single, oblong, one seeded berry with a terminal stigma and a fleshy pericarp. The dark brown fruit has an average weight and length of $3.46 \mathrm{~g}$ and 2.3 inches respectively. The seed obtained from splitting the fruits into two is oblong, ventrally grooved with a hard endosperm with an average weight of 1.06 g.

\subsection{Phytochemistry}

Both qualitative and quantitative phytochemical screening revealed the presence of alkaloids, flavonoids, saponins, tannins, terpenoids, steroids, phenols and combined anthraquinone while cardiac glycosides were absent (Table 1). These phytochemical constituents are also in varying quantities (Fig. 1).

Table 1: Qualitative phytochemical characteristics of Phoenix dactylifera

\begin{tabular}{|c|l|l|l|l|l|l|l|l|l|}
\hline Extracts & Alkaloid & Flavonoid & Tannin & Saponin & Terpernoid & Steroids & $\begin{array}{l}\text { Combined } \\
\text { Anthraquinone }\end{array}$ & $\begin{array}{l}\text { Phenol } \\
\text { Cardiac } \\
\text { Glycoside }\end{array}$ \\
\hline AQUEOUS & + & + & + & + & + & + & + & + & - \\
\hline & + & + & + & + & + & + & + & + & + \\
\hline ETHANOL & + & + & + & + & + & - & + & + & + \\
\hline & + & + & + & + & + & - & + & + & + \\
\hline $\begin{array}{l}\text { DIETHYL } \\
\text { ETHER }\end{array}$ & + & + & + & + & + & + & - & - \\
\hline & + & + & + & + & + & + & - & - & + \\
\hline $\begin{array}{l}\text { N- } \\
\text { HEXANE }\end{array}$ & + & + & + & + & + & + & - & - \\
\hline
\end{tabular}

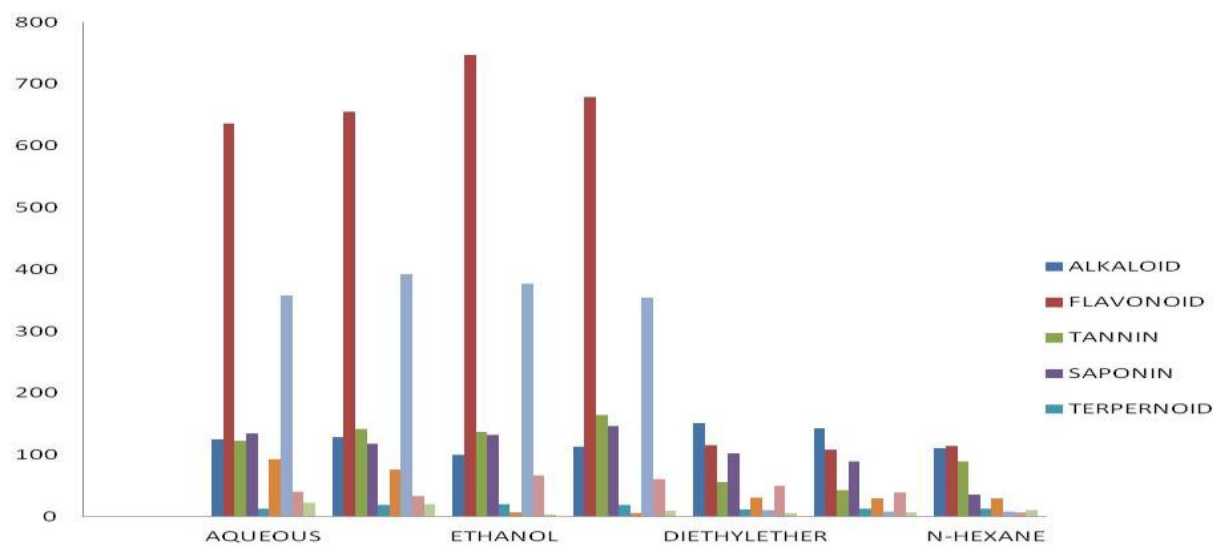

Figure 1: Chart showing the quantitative phytochemical analysis (in grams) of date fruit 


\subsection{Proximate Analysis}

The proximate analysis of the date palm shows us that it is very high in carbon, hydrogen and oxygen $(\mathrm{C}, \mathrm{H}, \mathrm{O})$ which are the starting block of carbohydrates $(71.5 \%)$ and contains low amount of proteins and lipids , $4.85 \%$ and $2.75 \%$ respectively. Moisture on the other hand is at $14.4 \%$ which is quite low, this is due to the process of sun drying before transportation of these fruits to different parts of the world to prevent spoilage (Fig 2).

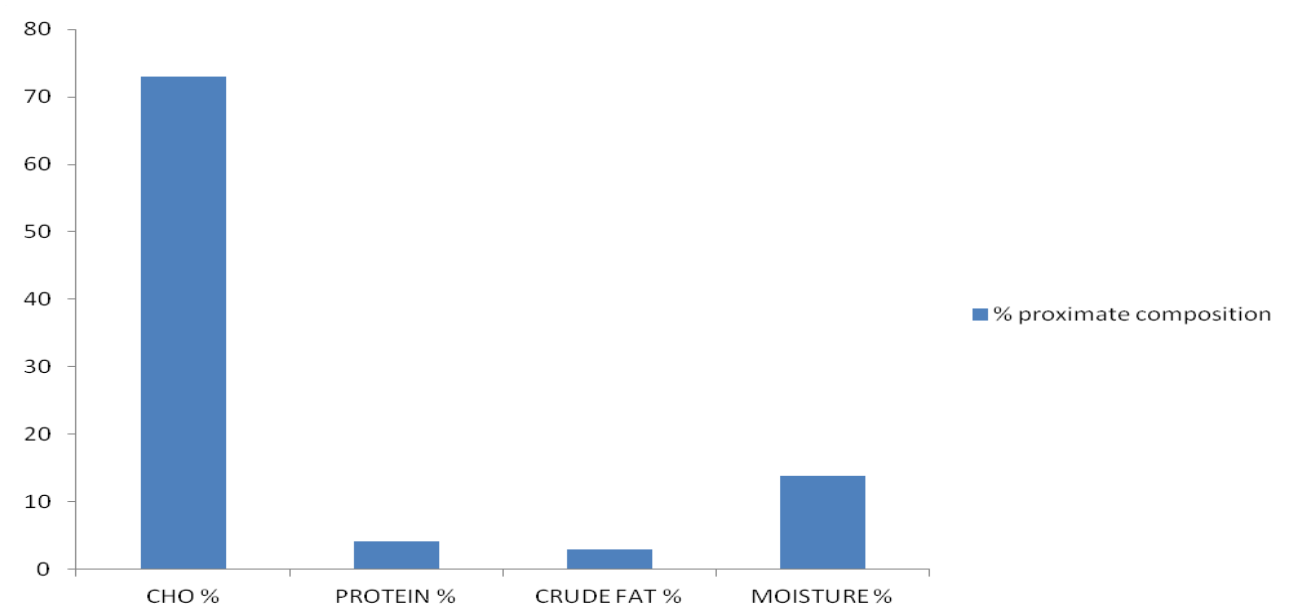

Figure 2: Chart showing the proximate composition (in percentage) of date fruit

\subsection{Antifungal Screening}

The screening for the antifungal activities of different concentrations, $200 \mathrm{mg} / \mathrm{ml}, 400 \mathrm{mg} / \mathrm{ml}$ and 1000 $\mathrm{mg} / \mathrm{ml}$ of the aqueous extract of date fruit compared with a standard fungicide, Fulcin showed these results: $11.0 \mathrm{~mm} \pm 0.5$ (A101) and $10.5 \mathrm{~mm} \pm 0.5$ (B101) in the $200 \mathrm{mg} / \mathrm{ml}$ date aqueous extract concentration, $12.0 \mathrm{~mm}$ \pm 0.5 (A101) and $13.0 \mathrm{~mm} \pm 0.5$ (B101) in the $400 \mathrm{mg} / \mathrm{ml}$ date aqueous extract concentration, $14.0 \mathrm{~mm} \pm 0.5$ (A101) and $15.0 \mathrm{~mm} \pm 0.5$ (B101) in the $1000 \mathrm{mg} / \mathrm{ml}$ date aqueous extract concentration, no inhibition zones for water which was used as the negative control, inhibition zones of $14.5 \mathrm{~mm} \pm 0.5$ in (A101) and $15.0 \pm 0.5$ in (B101) for Fulcin which is the positive control (Fig 3).

Figure 3: Antifungal activities of different concentration of aqueous extract of the date fruit in $\mathrm{mm}$.

The phytochemical analysis of this fruit has shown us that it is rich in different bioactive constituents, most especially in a group of plant chemicals known as phenols. These phenols have been found to be toxic and thus inhibit the growth of microorganisms in this case, fungi. The reason why some of these phytochemicals 
inhibit fungi growth is not fully known. It is possible that they act as inhibitors for enzyme systems as a result of their structural formulae but other reactions may be involved (Christie, 1965). The antifungal analysis of the date palm showed that increase in the concentration of the extract, was directly proportional to the increase in zones of inhibition of the fungi tested. Phytochemicals exert antimicrobial activity through different mechanisms; tannins for example, act by iron deprivation, hydrogen bonding or specific interactions with vital proteins such as enzymes (Scalbert, 1991) in microbial cells. Li et al. (2003) reported that tannins have remarkable activity in cancer prevention and anticancer, this suggests that date fruit could be a possible source of important bioactive molecules for the treatment and prevention of cancer. Alkaloids known for their toxicity against cells of foreign organisms was also observed in the date fruit (Ganguly and Sainis, 2001). Saponins, a well reported antimicrobial compound was also recorded.

\section{Conclusion}

From the result of this study, it can be concluded that the date fruits are a good source of minerals, and medicinally active constituents and they have good antifungal properties. The date fruit can be used as a natural antifungal agent for various food, fruits and their products. It is hereby recommended as a valuable and healthy food with a lot of health benefits and a viable raw material for the fungicide production industry.

\section{References}

[1]. Manickavasagan, A., Mohamed, M., Sukumar, E. In: Dates: Production, Processing, Food, and Medicinal Values. (CRC Press, 2012) 422.

[2]. Zaid, A. and de Wet, P.F. Date palm propagation, In: A. Zaid (ed.). Date palm cultivation, Food and Agriculture Organisation Plant Production and Protection Paper no. 156. (Rome, Italy: Food and Agriculture Organisation of the United Nations, 2002) 57-72.

[3]. Al-Yahyai, R. and Al-Kharusi. L. Physical and chemical attributes of freeze-stored dates. International Journal of Agriculture Biology, 14, 2012, 97-100.

[4]. Block, G., Patterson, B. and Subar, A. Fruit, vegetables and cancer prevention: a review of the epidermoloical evidence. Nutritional Cancer, 18(1), 1992, 1-29.

[5]. Tapiero, H., Tew, K.D., NguyenBa, G. and Mathé, G. Polyphenols: do they play a role in the prevention of human pathologies? Biomedicine Pharmacotheraphy, 56, 2002, 200-207.

[6]. Al-Quarawi, A. A., Ali, B. H., Mougy, S. A. and Mousa, H. M. Gastrointestinal transit in mice treated with various extracts of date (Phoenix dactylifera L.). Food and Chemical Toxicology, 41, 2003, 37-39.

[7]. El Hadrami, A., El Idrissi-Tourane, A., El Hassni, M., Daayf, F. and El Hadrami, I. Toxin-based in-vitro selection and its potential application to date palm for resistance to the bayoud Fusarium wilt. Comptes Rendus Biologie, 328, 2005, $732-744$

[8]. Foroogh, B., Abass, F. M. A., Liong, M. T., Azhar, M. E. Multivariate Statistical Analysis of Antioxidants in Dates (Phoenix dactylifera). International Food Research Journal, 15(2), 2008, 193-200.

[9]. Manjeshwar, S. B., Bantwal, R. V. B., Shaun, M. K., Harshith, P. B., Praveen, K. V. A review on the chemistry and pharmacology of the date fruits (Phoenix dactylifera L.). Food Research International. 44(7), 2011, 1812-1822.

[10]. Radford, A.E., Dickson, W.C., Massey, J.R. and Bell, C.R. Vascular Plant Systematics. (New- York: Harper and Row Publishers, 1974) 886.

[11]. Sofowora, A. Medicinal Plants and Traditional Medicine in Africa, (John Wiley and Sons Ltd., 1993) 150-153.

[12]. Christie, T. The effects of some phenolic compounds upon the growth of two species of Phytophthora. New Zealand Journal of Agricultural Research. 8(3), 1965, 630-635.

[13]. Ganguly T, Sainis KB. Inhibition of cellular immune response by Tylophora indica In experimental models. Phytomed. 8(5), 2001, 348-355. 